\title{
Perceived Effectiveness of the Anti-Smoking Public Service Advertisement on YouTube (\#SuaraTanpaRokok)
}

\author{
Rizanna Rosemary ${ }^{1}$, Novi Susilawati ${ }^{2}$, Deni Yanuar ${ }^{3}$, Nur Anisah ${ }^{4}$, and Mawaddah Idris ${ }^{5}$ \\ 1,2,3,4,5 Prodi Ilmu Komunikasi, Fakultas Ilmu Sosial dan Ilmu Politik, Universitas Syiah \\ Kuala, Banda Aceh
}

\begin{abstract}
Indonesia's tobacco control law enforcement remains weak and has not regulated the total ban on tobacco advertisement, promotion, and sponsorship bans (TAPS). Meanwhile, mediated anti-smoking messages have been significantly found to reduce smoking prevalence in many countries, helping people to stop smoking and preventing new smokers. Unfortunately, the anti-smoking Public Service Advertisements (PSAs) in Indonesia is unable to compete with the extensive and creative cigarette advertising or pro-smoking messages in many media platforms. Messages encouraging people to stop smoking and delivering the hazardous effects of smoking remain spotty in terms of numbers and visibility, leaving people with limited information about the adverse effects of smoking. There has been little research literature looking at how people perceived the effectiveness of antismoking messages. This study aims to identify and assess the anti-smoking PSAs by \#suaratanparokok. A content analysis is carried out to examine the perceived effectiveness of the \#suaratanparokok PSAs on YouTube. The involvement of YouTube influencers and optimizing social media platforms are important in delivering the PSAs. This study provides insights and recommendations to warn people about the danger of smoking through effective anti-smoking messages.
\end{abstract}

Keywords: Anti-Smoking; Perceived Effectiveness; Public Service Advertising; YouTube

\section{INTRODUCTION}

\section{Smoking Prevalence in Indonesia}

Indonesia is still a smoker's paradise. The number of smokers in Indonesia is the third highest in the world. With a total population of $267,670,548$ in 2018, more than half of the male population are smokers. The Indonesian Basic Health Research (Riskesdas) in 2018 showed that the percentage of adult smokers is $62.9 \%$ and $33.8 \%$ are adolescents smokers aged 13-15. Based on data from the Southeast Asia Tobacco Control Alliance (Seatca, 2018), Indonesia ranks first for the highest number of smokers in Southeast Asia, with $67 \%$ male smokers, including youth smokers. 
Even though the number of women who smoke remains small $-6.7 \%$ (2018), there is an increasing trend of female smokers every year. The increase is found among hidden smokers, that is women who choose to smoke in private. The increase of the hidden smokers has an impact on the less visible number of female smokers compared to men documented through surveys (Rosemary, 2020). Lack of efforts to seriously control tobacco in the country resulted in a high number of deaths due to smoking among passive and active smokers. Globocan (2018) states that lung cancer due to smoking contributes to the primary death in the country (12.6\%) which supports the data from a prominent hospital in Jakarta-Rumah Sakit Umum Pusat Persahabatan that that lung cancer cases reported correlates to tobacco use (Badan Penelitian dan Pengembangan Kesehatan, 2018).

Furthermore, although the public is aware of the hazardous effects of smoking, the numbers of smokers continue to increase every year. The incomprehensive tobacco control regulation, including no total ban on tobacco advertising, promotion, and sponsorships (TAPS) has an impact on the high smoking rates in Indonesia. This condition has negative implications for health, economic, social, and various aspects of people's likelihood (Seatca, 2018; Drope et al., 2018).

\section{Cigarette Advertising and Teen Smoking Behaviours}

A number of studies revealed many factors contribute to smoking behavior in adults (Jefferis et al., 2003); women (Graham \& Der, 1999; Manaf \& Shamsuddin, 2008); adolescents (Ennett \& Bauman, 1994; Kandel \& Wu, 1995); and children (Jackson \& Henriksen, 1997). Most studies found that family members and peers' influence is the main reason for adolescents' smoking onset (Lucas \& Lloyd, 1998).

Moreover, many studies indicated a direct correlation between exposure to cigarette advertisements and smoking initiation in adolescents (Luke C, 2007; Davis et al., 2008; Sargent et al., 2009). Mass media is argued to have powerful effects in influencing adolescents to start smoking, in particularly when the young groups are high exposed to tobacco advertisements. Likewise, exposure to pro-smoking messages through the media is found to contribute to youth smoking behavior in Indonesia (Nichter et al., 2009; Sebayang et al., 2012; Prabandari et al., 2016; Putra et al., 2020). The messages encouraging people to smoke are placed and found in many media platforms, such as electronic media (television and radio), printed media (newspapers, billboards (Luke, 2007; Luke et al., 2000, Putra et al., 2020), and new media or online platforms (Freeman, 2010; Astuti et al., 2018).

The weak law enforcement in smoke-free areas, the low price of cigarettes, and no total restriction of TAPS resulting in children becoming new smokers. Data from the Global Youth Tobacco Survey (GYTS) in 2019 showed that 7 out of 10 students have seen cigarette advertising promotions through television, sales venues, and social media channels (WhoIndonesia, 2020). Based on the GYTS data in 2014, adolescent smokers 
started smoking at the age of $12-13$ years (43.2\%) and $11.4 \%$ at the age of $14-15$ years, while children below seven years old have attempt to smoke.

\section{Warning The Hazardous Effects of Smoking Through PSA (Public Service Advertisement)}

Besides encouraging people to smoke, the media also has a role in encouraging people to quit smoking or preventing people from becoming new smokers, especially among children and adolescents (Luke et al., 2000), through the placing pictorial health warnings on cigarette packages and Public Service Advertisement (PSA) on the media. Both media interventions deliver message about the adverse effects of cigarette consumptions and aim to encourage people not to smoke or to quit smoking.

The Ministry of Health of the Republic of Indonesia (Kemenkes RI) has implemented both interventions to protect the people's health. The government's efforts to control tobacco consumption and production is addressed in the regulation, Peraturan Pemerintah (PP) 109/2012 about tobacco control. Besides restricting TAPS, the regulation imposed the obligation for central and local government to educate the people about the hazardous effects of smoking through Public Service Advertisement (PSA), which is stated in article 32: "Dalam rangka memenuhi akses ketersediaan informasi dan edukasi kesehatan masyarakat, Pemerintah dan Pemerintah Daerah menyelenggarakan iklan layanan masyarakat mengenai bahaya menggunakan Produk Tembakau (Peraturan Pemerintah Republik Indonesia, 2012).

Indonesia is still behind other Southeast Asian countries in terms of pictorial health warnings (PHW) on cigarette packaging. Indonesia applied 40\% PHW on the pack of cigarettes. In 2015, the Tobacco Control Support Center - the Indonesian Association of Public Health Experts (TCSC - IAKMI) in collaboration with tobacco control agencies in several cities in Indonesia carried out a national survey on the Compliance of Pictorial Health Warning Implementation in Indonesia. The result found (a) low compliance of cigarette industry in applying the 40\% PHW on cigarette packaging; (b) smokers have ways to avoid and ignore these pictorial health warnings, such as exchanging cigarette packs for other packs that have less scary images and replacing cigarettes to empty boxes; and (c) purchasing single-stick cigarettes (Soerojo, 2014; Rosemary, 2020). The national survey concluded that controlling cigarette consumption through applying the $40 \%$ PHW policy on cigarette packaging is considered ineffective due to low industry compliances on the regulation and lack of people's awareness of the harmful effects of smoking.

Furthermore, the Indonesian Ministry of Health has produced and disseminated antismoking Public Service Advertisements (PSAs) containing messages on the hazardous effects of smoking and recommendations to quit smoking. However, PSAs are still lacking in terms of the quantity and the quality of contents/messages. Particularly when compared to the cigarette advertisements (TAPS) which remain accessible in various 
media sites although is prohibited under the PP No. 109/2012 (Government Regulation of the Republic of Indonesia, 2012). The PSAs production process in Indonesia is based on research evidence. Mostly adopting current PSAs which are found successful and effective in reducing smoking prevalence in the western and other developed countries (Durkin et al, 2013; Rosemary, 2020).

Through collaboration with the global public health organization engaged in media campaigns and advocacy-Vital Strategies (for Indonesia), the Indonesian Ministry of Health has produced around eight official PSAs since 2014 and broadcasted them in mainstream media such as TV, radio, and online, like YouTube. The dissemination of the PSAs was a collaboration process with \#suaratanparokok. \#Suaratanparokok is a movement enabling passive smokers and former active smokers to inspire other people by speaking up about the need to quit smoking. The movement engaged partnerships with many non-profit cigarette control organizations in Indonesia.

The evaluation study of four anti-smoking PSAs produced by the Indonesian Ministry of Health and VSI (at that time called the World Lung Foundation-WLF) found that people tend to choose PSAs with more emotional appeal. The PSAs are in the form of testimonials addressing the harms of smoking. For example, PSAs about Pak Panjaitan, Ibu Ike, and Roby (WLF, 2015). The result of this evaluation study is different from previous studies that argued messages displaying health effects of smoking (fear appeal health graphics) are more effective (Fauzi et al., 2018).

Recent studies exploring women's interpretations and responses to anti-smoking PSAs have shown relatively contradictory results. The results of the study showed that the implementation of anti-smoking PSAs adopting the 'global message approach', that is fear appeal is ineffective because people do not find the message representing the sociocultural context of the local community. In addition, the current anti-smoking PSAs (Ibu Ike and Robby versions) said to not meet people's needs and expectations of meaningful messages about the hazardous effects of smoking (Rosemary, 2020). From these various studies, it shows that the development of PSAs needs to take into account the targeted audiences and their cultural context.

\section{Anti-Smoking PSAs on YouTube}

Since cigarette advertisements are partially banned on mainstream media as regulated by PP 10/2012, tobacco advertisement, promotion, and sponsorships (TAPS) have made use of online media to promote their products (Rosemary, 2011; Astuti et al., 2018; Mutmainnah et al., 2020). However, monitoring and controlling cigarette advertisements on online media (internet) remains controversial. The Ministry of Health has issued an appeal to block the internet from cigarette advertisements in mid-June 2019 as a response to the amount of pressure to ban cigarette advertisements online. However, this effort continues to face challenges from various parties, especially the Indonesian Advertising Association and the tobacco industries. 
Likewise, some individuals, NGOs, and the government have switched to use online media, such as YouTube, to place and broadcast anti-smoking PSAs. The expensive cost of placing advertisements in mainstream media, such as television, is said to be the reason for the Ministry of Health's reluctance to place and disseminate the anti-smoking message on electronic media such as TV.

Several studies have evaluated audience/viewer responses to the effectiveness of the PSAs about the dangers of smoking on YouTube (Chung, 2015; Hong et al., 2013; Shi et al, 2014). The effectiveness of the advertising message is determined by three factors (a) exposure, or frequency of video content viewed; (b) engagement, the number of people involved in the content discussion; and (c) insight, response, or opinion on the video watched (positive, neutral, or negative). The third factor was analyzed from the viewer's comments on the video they watched.

The study found that positive comments supporting video content can strengthen the content of the advertising message and support the goals of the messenger. For example, the following comment, "I am a former smoker. . . and believe me. . . You don't want to take on this bad habit." "I'm an ex-smoker... believe me... you don't want to get involved in this addiction.") (Chung, 2015). Relatively similar results were found in studies conducted in America, assessing the impact of online comments and smokers' perceptions of existing anti-smoking PSAs (Shi et al., 2014).

There is no study in Indonesia found to evaluate audiences' perception and the response of the anti-smoking PSAs through social media like YouTube, including the absence of studies that comprehensively examine how the forms of PSAs are considered effectively liked and considered meaningful by the public. Therefore, this study aims to identify and analyze the \#suaratanparokok anti-smoking PSAs on YouTube.

\section{METHODOLODY}

This study uses a quantitative approach where data collection is carried out through content analysis techniques, namely collecting, coding, and analyzing \#suaratanparokok videos. The selection of \#suaratanparokok PSAs is to evaluate the effectiveness of official PSAs produced and issued by the government in collaboration with Vital Strategies Indonesia (VSI) and tobacco control institutions in Indonesia.

\#Suaratanparokok is a movement aimed at accommodating the voices and experiences of passive smokers and ex-active smokers. This movement is carrying out a campaign to encourage people to quit smoking and to inspire people to have a voice in controlling tobacco products. \#SuaraTanpaRokok campaigns run actively through social media platforms, including YouTube, Facebook, Twitter, and Instagram. 
By entering the keyword suara tanpa rokok into YouTube's search engine, we found several videos that had all three of these keywords. We also ensure that the videos are joint production of VSI in collaboration with the Ministry of Health of the Republic of Indonesia.

The researchers conducted the coding of 23 videos. Coding of the anti-smoking PSAs refers to the concept of perceived effectiveness of PSAs, which includes counting the number of people watching or exposed by the video (exposure), the number of users' involvement (engagement), and the number of responses by YouTube viewers (insights). The amount of exposure is determined based on the number of viewers of the video watched. Meanwhile, the number of engagements is measured by the number of people who commented on the video, as well as tracking for likes and dislikes. The number of responses is calculated by the comments given comments column, that is, looking at the tone of the comments whether positive, neutral, and negative. The content analysis process was carried out in six ( 6 days) in October 2020 by all the research teams. All videos were accessed and analysed as of November 26, 2020.

\section{RESULT AND DISCUSSION}

Based on the observations, there are 23 videos with hashtags suara tanpa rokok (\#suaratanparokok). The \#suaratanparokok PSAs deliver stories from active and passive smokers conveying information that smoking has an impact on both active and passive smokers and raising people's awareness to stop smoking. The results of the content analysis revealed variations in the number of exposure, engagement, and audiences' insights about the anti-smoking PSAs. The content analysis of \#suaratanparokok videos found the highest number of exposures was the video entitled Rokok murah, obatnya yang mahal' - Kisah Robby Indra Wahyuda with 526,921 viewers, 73 viewers' involvement, and seven responses. The video is about a person who is an active smoker suffered a larynx and lung cancer and died at the age of 26. The risk of getting larynx and lung cancer is mostly due to exposure to cigarette smoke, as Dr. Daniel Tan, Senior Consultant, National Cancer Center Singapore (NCCS) said that "A smoker's risk of lung cancer is 15 to 25 times that of a non-smoker".

The next highest number of exposures is the video called Bahaya Paparan Asap Rokok (Ibu Ike), having 333,719 viewers and a total of 80 viewers' involvement with 13 responses. The message from the video describes the impact of smoking exposure on secondhand smoker. Ibu Ike had a vocal cord cancer that caused her to lose the vocal cords and disable her to speak clearly. Table 1 summarizes the coding of the three perceived effectiveness in the 23 videos. 
Figure 1. Screenshots of \#suaratanparokok video keyword search

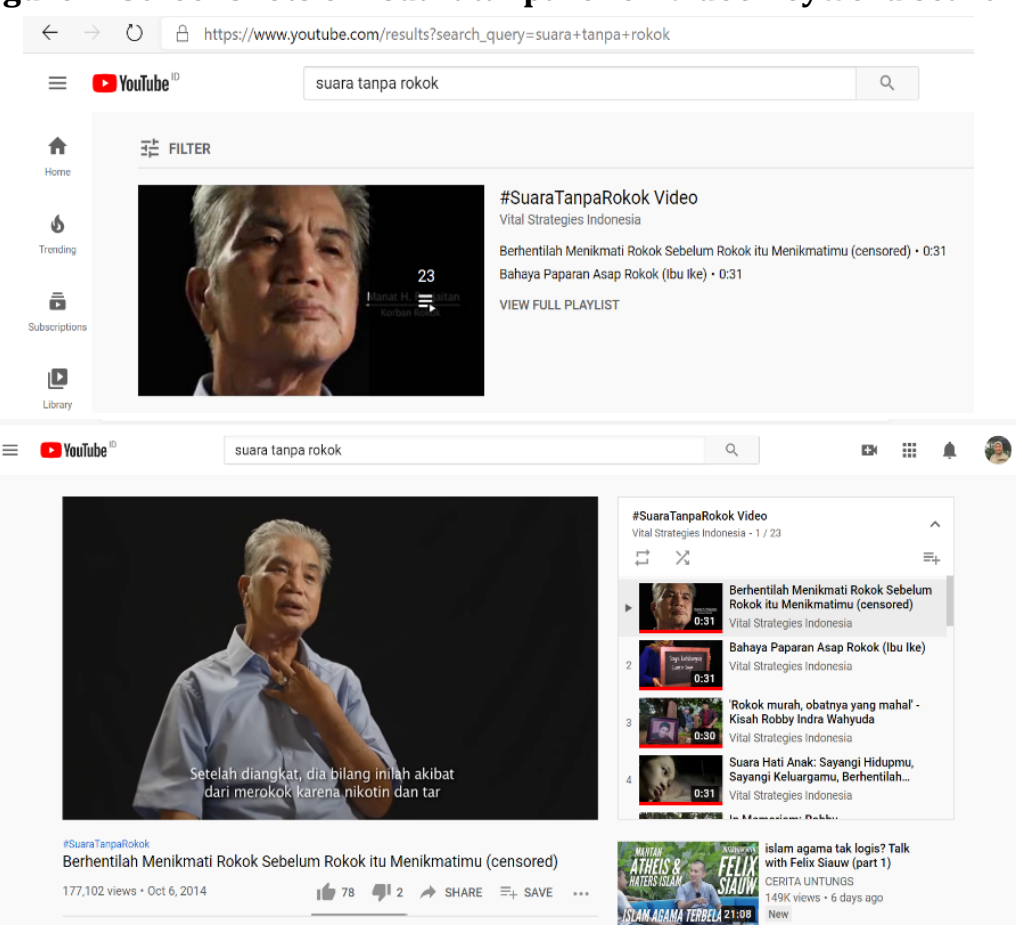

Source: YouTube (accessed on 26 November 2020)

Table 1. Coding of \#suaratanparokok PSAs

\begin{tabular}{|c|l|c|c|c|c|c|c|c|}
\hline \multirow{2}{*}{ No } & \multirow{2}{*}{ Video Title } & $\begin{array}{l}\text { Number of } \\
\text { Exposure }\end{array}$ & \multicolumn{2}{|c|}{ Number of Engagement } & \multicolumn{3}{|c|}{ Number of Responses } \\
\cline { 2 - 8 } & Viewers & Like & Dislike & Comment & Positive & Negative & Neutral \\
\hline 1 & $\begin{array}{l}\text { In } \\
\text { Memoriam: } \\
\text { Robby }\end{array}$ & 57.364 & 294 & 20 & 38 & 23 & 3 & 12 \\
\hline 3 & $\begin{array}{l}\text { Kisah Cecep } \\
\text { Sopandi - } \\
\begin{array}{l}\text { Penderita } \\
\text { Penyakit } \\
\text { Buerger }\end{array}\end{array}$ & 2.778 & 10 & 2 & 14 & 14 & 0 & 0 \\
\hline $\begin{array}{l}\text { Bahaya } \\
\text { Paparan } \\
\text { Asap Rokok } \\
\text { (Ibu Ike) }\end{array}$ & 333.719 & 67 & 3 & 13 & 5 & 3 & 5 \\
\hline & $\begin{array}{l}\text { Berhentilah } \\
\text { Menikmati } \\
\text { Rokok } \\
\text { Sebelum } \\
\text { Rokok itu } \\
\text { Menikmatim } \\
\text { u (censored) }\end{array}$ & 176.802 & 78 & 2 & 7 & 4 & 2 & 1 \\
\hline 5 & $\begin{array}{l}\text { Rokok } \\
\text { murah, } \\
\text { obatnya } \\
\text { yang mahal' - } \\
\text { Kisah Robby }\end{array}$ & 526.921 & 63 & 3 & 7 & 1 & 0 & 6 \\
\hline
\end{tabular}




\begin{tabular}{|c|c|c|c|c|c|c|c|c|}
\hline & $\begin{array}{l}\text { Indra } \\
\text { Wahyuda }\end{array}$ & & & & & & & \\
\hline 6 & $\begin{array}{l}\text { Batuk } \\
\text { Perokok - } \\
\text { Quitline } \\
0800-177- \\
6565\end{array}$ & 5.114 & 22 & 4 & 7 & 3 & 1 & 3 \\
\hline 7 & $\begin{array}{l}\text { Penyakit } \\
\text { yang } \\
\text { Diakibatkan } \\
\text { Rokok }\end{array}$ & 250.039 & 36 & 2 & 4 & 1 & 1 & 2 \\
\hline 8 & $\begin{array}{l}\text { Suara Hati } \\
\text { Anak: } \\
\text { Sayangi } \\
\text { Hidupmu, } \\
\text { Sayangi } \\
\text { Keluargamu, } \\
\text { Berhentilah } \\
\text { Merokok! }\end{array}$ & 108.331 & 46 & 0 & 3 & 3 & 0 & 0 \\
\hline 9 & $\begin{array}{l}\text { \#TheyLieWe } \\
\text { Die - } \\
\text { Cilandak } \\
\text { Town Square }\end{array}$ & 330 & 5 & 1 & 2 & 2 & 0 & 0 \\
\hline 10 & $\begin{array}{l}\text { Rokok } \\
\text { Menghancur } \\
\text { kan } \\
\text { Hidupmu }\end{array}$ & 317.736 & 27 & 2 & 3 & 1 & 1 & 1 \\
\hline 11 & $\begin{array}{l}\text { \#TheyLieWe } \\
\text { Die } \\
\text { Banjarmasin }\end{array}$ & 125 & 1 & 0 & 1 & 1 & 0 & 0 \\
\hline 12 & $\begin{array}{l}\text { Tunjukkan } \\
\text { Warna } \\
\text { Aslimu - Kali } \\
\text { Code (1 } \\
\text { menit) } \\
\end{array}$ & 136 & 0 & 0 & 0 & 0 & 0 & 0 \\
\hline 13 & $\begin{array}{l}\text { Asapmu } \\
\text { Membunuh } \\
\text { Orang di } \\
\text { Sekitarmu - } \\
\text { Quitline } \\
0800-177- \\
6565 \\
\end{array}$ & 104.390 & 14 & 0 & 0 & 0 & 0 & 0 \\
\hline 14 & $\begin{array}{l}\text { Tunjukkan } \\
\text { Warna } \\
\text { Aslimu - } \\
\text { Bogor (1 } \\
\text { Menit) } \\
\end{array}$ & 100 & 0 & 0 & 0 & 0 & 0 & 0 \\
\hline 15 & $\begin{array}{l}\text { \#KadaHanda } \\
\text { kRokok } \\
\text { (Tidak Mau } \\
\text { Rokok) }\end{array}$ & 206 & 5 & 0 & 0 & 0 & 0 & 0 \\
\hline
\end{tabular}


9 Perceived Effectiveness of the Anti-Smoking Public Service Advertisement on YouTube (\#SuaraTanpaRokok) | Rizanna

\begin{tabular}{|c|c|c|c|c|c|c|c|c|}
\hline 16 & $\begin{array}{l}\text { \#TheyLieWe } \\
\text { Die - } \\
\text { Yogyakarta }\end{array}$ & & 1 & 0 & 0 & 0 & 0 & 0 \\
\hline 17 & $\begin{array}{l}\text { Kisah Ranap } \\
\text { Simatupang - } \\
\text { Penderita } \\
\text { Kanker Paru } \\
\text { Stadium } 4\end{array}$ & 1.772 & 13 & 0 & Ditutup & 0 & 0 & 0 \\
\hline 18 & $\begin{array}{l}\text { Kesempatan } \\
\text { Kedua } \\
\text { Richard - } \\
\text { Penderita } \\
\text { Penyakit } \\
\text { Paru } \\
\text { (Pneumotho } \\
\text { rax) Akibat } \\
\text { Merokok }\end{array}$ & 242 & 2 & 0 & 0 & 0 & 0 & 0 \\
\hline 19 & $\begin{array}{l}\text { Kisah Relis } \\
\text { Gultom - Istri } \\
\text { Alm. Ranap } \\
\text { Simatupang }\end{array}$ & 276.612 & 11 & 2 & 0 & 0 & 0 & 0 \\
\hline 20 & $\begin{array}{l}\text { Aksi } \\
\text { \#TheyLieWe } \\
\text { Die Bali }\end{array}$ & 192 & 12 & 4 & 0 & 0 & 0 & 0 \\
\hline 21 & $\begin{array}{l}\text { Bogor } \\
\text { \#TeuHayang } \\
\text { Rokok (Say } \\
\text { no to } \\
\text { cigarette) } \\
\text { Campaign }\end{array}$ & 35 & 0 & 0 & 0 & 0 & 0 & 0 \\
\hline 22 & $\begin{array}{l}\text { Kampanye } \\
\text { \#SengMauRo } \\
\text { kok - Ambon } \\
\text { (1 menit) }\end{array}$ & 38 & 0 & 0 & 0 & 0 & 0 & 0 \\
\hline 23 & $\begin{array}{l}\text { Kesempatan } \\
\text { Kedua } \\
\text { Richard - } \\
\text { Penderita } \\
\text { Penyakit } \\
\text { Paru } \\
\text { (Pneumotho } \\
\text { rax) Akibat } \\
\text { Merokok }\end{array}$ & 123.476 & 19 & 1 & 3 & 3 & 0 & 0 \\
\hline
\end{tabular}

Source: YouTube (accessed on 26 November 2020)

\section{Exposures to Messages}

The analysis of the \#suaratanparokok PSAs on YouTube showed variations in the number of exposures for each video. Video with the title Rokok murah, obatnya yang mahal' - Kisah Robby Indra Wahyuda illustrates the largest number of viewers-526,921 (until access on November 26, 2020). However, the number of viewers' engagements for this video is 
less (7 comments) when compared to the same version of Robby with a different title - In memoriam: Robby (38 comments).

The video In memoriam: Robby has the highest number of viewers' engagements. This video tells a story of a young active smoker name Robby Indra Wahyuda's and his experience fighting for vocal cord cancer but unfortunately died at the age of 26 . The content analysis demonstrated that PSAs raising messages about the hazardous effects of smoking in the form of testimonials from the victims or victims' families was more appealing because they influence audiences' emotions than messages displaying the graphic health effects. These results confirm a survey conducted by VSI, Indonesian people prefer and accept testimonial messages than scary images displaying severe diseases caused by smoking (WLF, 2015).

However, the large number of viewers does not guarantee the videos watched have direct comments (involvement) from viewers or whether they enjoyed the videos. It is likely difficult to trace the exact numbers of viewers' exposures to the video watched. Even though the availability of like and dislike icons are expected as a tool to measure if the messages has an influence to the public, the observation of people's behaviour in watching YouTube, show that (1) many people watch the video but do not directly give feedback by pressing the like and dislike buttons, (2) many people watch without giving comments, (3) many people only watch the video in terms of the quality of the content, not by the message conveyed, and (4) same person may watched the same video several increased the number of viewers.

Based on the YouTube viewers' behavior, it can be said that a large number of likes and viewers cannot fully be used as a measuring tool to examine the public's response and acceptance of the anti-smoking PSAs. For instance, the video 'In memoriam: Robby', received the most likes-297 and 57,461 viewers when compared to the same video with the title Berhentilah Menikmati Rokok Sebelum Rokok itu Menikmatimu (censored) which only received 78 likes and watched about 177,415 times. The latter video has fewer likes but watched more than 'In memoriam: Robby'.

To understand how tobacco advertising (both commercial and PSA) is broadcasted on YouTube, we compared the cigarette advertisement placed by the Iklan Digital Indonesia account with the anti-smoking PSA posted by Vital Strategies Indonesia. Table 2 provides the visual comparison of both ads. 
Table 2. Comparison of Tobacco Commercial Ad and Anti-Smoking PSA

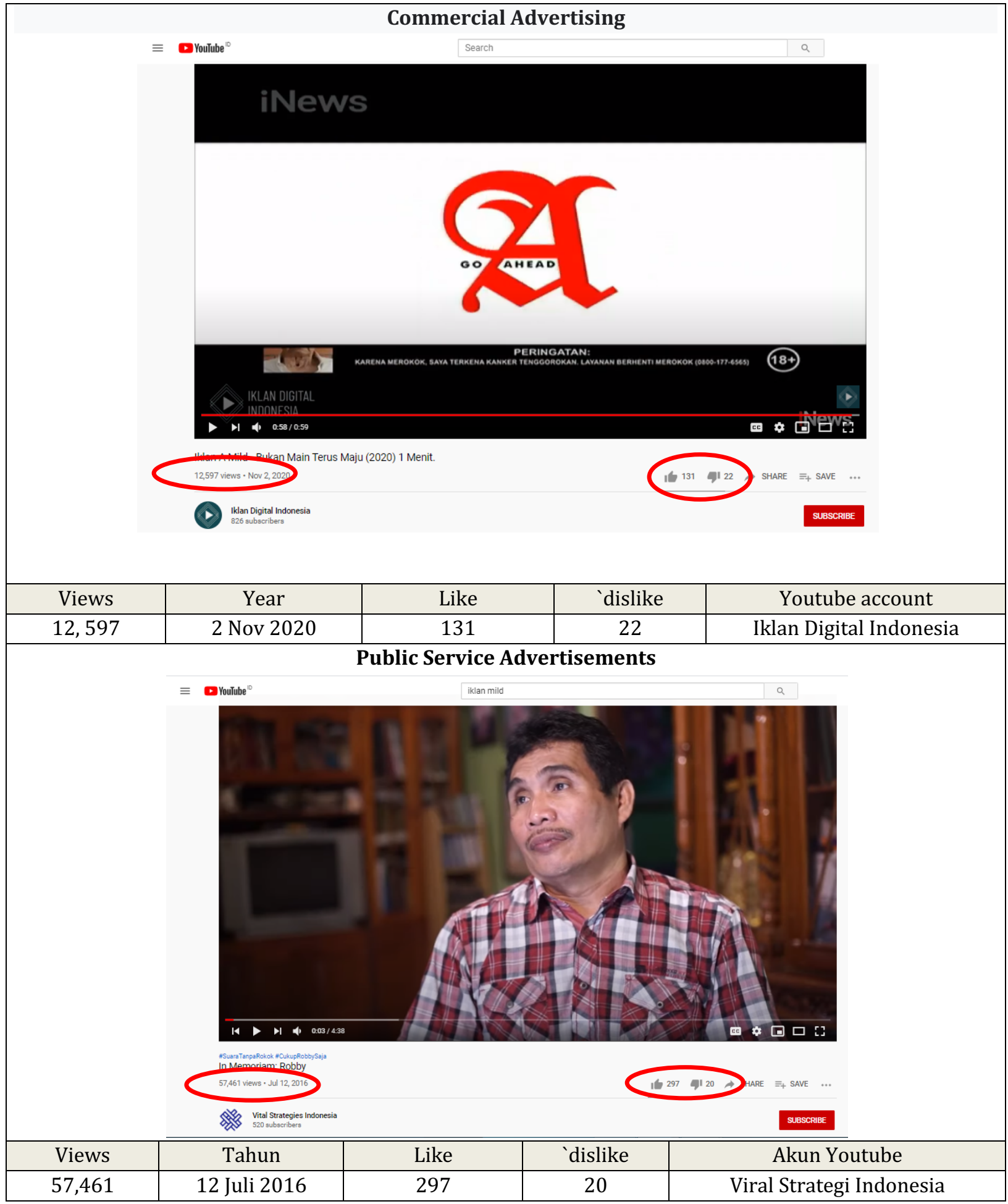

Source: YouTube (accessed November 26, 2020)

From the comparison table above, the commercial ads with the title Iklan A Mild -Bukan Main Terus Maju (2020) received the most viewers in a month with 12,597 viewers and 131 likes. Meanwhile, the PSA with the title In memoriam: Robby received 57, 461 viewers and 297 likes in four (4) years. The number of PSAs viewers is higher than the commercial ad, but the video was uploaded in the last four years ago. In contrast, viewers for tobacco commercial advertising which was posted within one month has exceeded the anti- 
smoking PSA. It can be said that cigarette commercial ads aimed to encourage people to smoke have higher audiences' interest compared to the anti-smoking PSA which asking people to give up smoking.

\section{VIEWERS' ENGAGEMENTS AND RESPONSES}

Out of 23 \#suaratanparokok videos uploaded, 19 videos received a varied number of viewers. The highest likes were obtained by the video In memoriam: Robby (294), while the videos \#TheyLieWeDie Banjarmasin and \#TheyLieWeDie Yogyakarta received the lowest likes respectively, only one. Furthermore, out of 23 videos, 12 videos received positive responses from viewers. Video In memoriam: Robby received the highest positive response, while four videos received the lowest response, Rokok murah, obatnya yang mahal' - Kisah Robby Indra Wahyuda, Penyakit yang diakibatkan Rokok, Rokok Menghancurkan Hidupmu, and \#TheyLieWeDie Banjarmasin. Based on 23 videos uploaded by PSAs \#suaratanparokok, 11 videos have no responses from viewers.

Based on the videos coded, not all viewers who watch \#suaratanparokok PSAs want to press the like and dislike buttons or leave either positive or negative responses. This study also shows that many viewers are exposed to the Kisah Robby Indra Wahyuda video, but there are fewer viewers who press the like icon when compared to the shorter version of Robby's story. This indicates that although the video and message conveyed are interesting, the long duration of the video makes viewers reluctant to comment compared to videos with a shorter duration with straight forward information. The 'In memoriam: Robby' video has a 04.39 minutes duration, and many responses found at the comment column, ranging from negative and positive responses. The following are examples of viewers' responses.

"Innalillahi wa inna ilaihi rojiun .... Turut Berduka Cita, kami sekeluarga. Sungguh saya prihatin dengan Bahaya Merokok ini. Jadi, marilah kita menyadari pentingnya hidup bebas asap rokok ataupun merokok itu sendiri. Saya menghimbau khususnya diri saya sendiri ... Memang Dosa Tidak di Wariskan, namun akibat dari Dosa adalah DIWARISKAN." (Translated as "Innalillahi wa Innailaihirojiun .... our deep condolence. I'm really concerned about the harms of smoking. So, let us realize the importance of living smokefree or avoid smoking. I encourage myself ... It is true that sin is not inherited, but the result of sin is inherited."

Figure 2. Screenshot of 'In memoriam: Robby' PSA

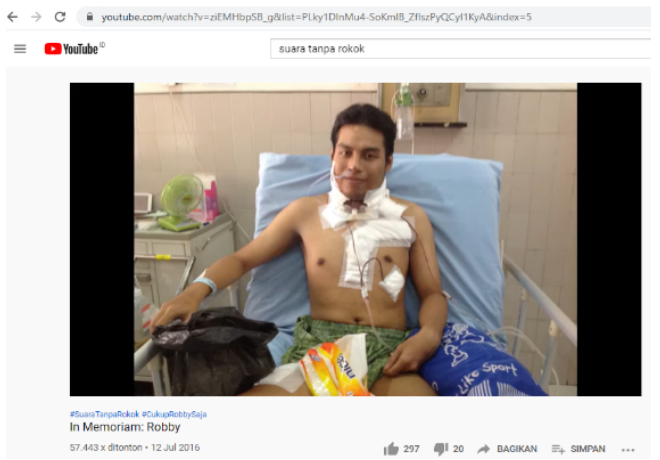

Source: YouTube (accessed on 26 November 2020) 
Prevention intervention of the dangers of smoking can reduce the spread of diseases caused by smoking both for active and passive smokers. The difficulty to quit smoking addiction is felt by some smokers. For example, a positive response was given by viewers on the video as follows:

"Saya sdh berhenti 2 minggu. Masih awal. Tp saya selalu menonton tentang bahaya merokok untuk ingatkan supaya jgn sampai merokok lagi."Dulu gara2 rokok aku di vonis dokter spesialis paru TBC Setelah berobat 8 bln jalan dgn obat paket puskemas alhamdulilah aku sembuh total yg dulu berat badan cuma $50 \mathrm{~kg}$ kini setahun lebih stop rokok berat badan sdh $75 \mathrm{~kg}$ (translated as "I have quit smoking for two weeks. It still an early stage. But I always watch about the hazardous effects of smoking to remind me not to smoke again. Because of smoking, I was diagnosed with pulmonary by a tuberculosis specialist. After eight months of medical treatment at the health care center, thank God, I am completely cured. Previously, I weighed only $50 \mathrm{~kg}$, now it's over a year since I have stopped smoking, my body now weights 75kg.").

Despite various efforts made by the government through anti-smoking PSAs through mass media platforms, as well as placing pictorial health warnings on cigarette packs, not all people are aware of the adverse effects of smoking. These efforts are to provide the public with knowledge and understanding that smoking is dangerous. However, many people still ignore the message and gave negative and sarcastic responses as follows:

"Biarlah yg merokok ya merokok. asal jangan merugikan yang lain."

"teruslah merokok karena dengan tidak merokok akan dibilang enggak gaul...enggak setia kawan...enggak jantan...hehehe." (Translated as "Let those who smoke. as long as they don't harm others." "Keep on smoking because by not smoking you will be called not up to date ... not loyal, my friend ... not manly ... hehe"

In another video uploaded by \#suaratanparokok entitled Bahaya Paparan Asap Rokok (Ibu Ike), the video with a duration of 00:31 seconds tells the story about Ibu Ike Wijayanti, a secondhand smoker with vocal cord cancer due to smoking exposure. One viewer gave a negative response to the Ibu Ike PSA:

"ah lebay...kalo emang sebahaya itu kenapa rokok ga dilarang??siapa yang salah???ratusan orang yang aku kenal mereka pada ngerokok...dan ga ada yang kena kangker tenggorokan..coba poling yuk..siapa yang didekat rumahnya ada pengidap kangker tenggorokan tapi bukan perokok???" (Translated as "get over it ... if it's that dangerous why smoking is not banned ?? what's wrong ??? hundreds of people I know they smoke ... and no one got cancer in their throat ... let's do a polling ... who's throat cancer but not a smoker and lives nearby???")

From these comments, other viewers replied to the comments on the same post denying that cigarettes are not dangerous: 


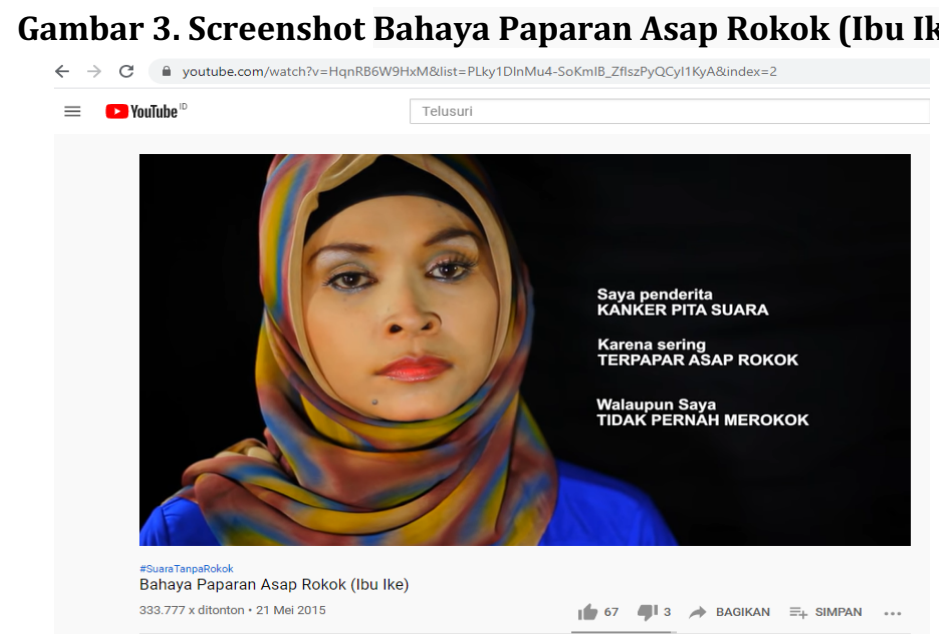

Source: YouTube (accessed on November 26, 2020)

"buat yang setuju dan anggap iklan ini lebai..silahkan aja..bebas kok..ini sosmed..tp setidaknya kita bisa ambil nilai positif dari iklan ini..untuk diri kita pribadi...dan tidak perlu diutarakan di media sosial..karena itu sangat mempengaruhi penilaian orang terhadap diri anda..sayangilah diri kita masing masing." (Translated as "For those who agrees and thinks that this ad is too much ... just go ahead ... it's free ... it's social media ... but at least we can take the positive value of this ad ... for ourselves ... and it doesn't need to be expressed on social media because it influences people's judgment of yourself. loves ourselves.")

These comments indicate that people who are aware of the dangers of smoking are aware of the consequences of smoking, which is not only detrimental to themselves but also the people around them and can also damage the young generation. Therefore, prevention is better than the late regret as a result of consuming cigarettes.

Many studies have shown how high exposure to cigarette advertisements affects student smoking behaviour (Prabandari et al., 2016; Putra et al., 2020). The continuous tobacco advertising exposures has an impact on increasing people's memory of the products promoted through these advertisements. Anti-smoking PSAs need to carry out strategy involving social media influencers to increase the frequency of exposure to the messages they want to convey. Given the word about the dangers of smoking, it will be hard to compete with cigarette TAPS through paid advertisement on mass media. Therefore, YouTube is one of the most effective media placements which is cost-effective for PSAs placement on the dangers of smoking. Media placement to reduce advertising costs is significant since anti-smoking PSAs cannot compete with advertisements in the mass media. Therefore, in delivering the tobacco counter advertising, there is a need to involve active social media influencers because they have big influence targeting young people.

The expansion of cigarette advertisements is massive. The absence of comprehensive tobacco control regulation in mainstream and online media will make even harder to stop the tobacco industry's strategy through TAPS. Thus, it is imperative to amend PP 109/2012 about tobacco control and the Broadcasting Law to regulate total ban on TAPS. Moreover, the central and local government need to produce and apply message in article 
32 PP 109/2012 that is providing public health information and education about the hazardous effects of smoking through developing effective and meaningful anti-smoking PSAs (Government Regulation of the Republic of Indonesia, 2012).

More anti-smoking PSAs are needed in terms of quantity and quality. The content of the PSAs should be improved and made more attractive and appealing. The existing antismoking PSAs are likely to convey and display message of suffering, pain, and death. A current study about people's interpretation of the anti-smoking PSAs found that the public refused to accept and absorb these negative messages due to the fatalistic religious belief practiced by majority of the people in Indonesia, which is predominantly Muslim. They believe that sickness and death are pre-determined by the God, the creator (Rosemary, 2020).

The content of the PSAs cannot be only in the form of visual ads but need to address positive messages. For example, informing people who don't smoke are cool than those who smoke. A positive message like this example will be more interesting than narrating negative aspects such as pain and death.

\section{CONCLUSION}

This study focuses on \#suaratanparokok Public Service Advertisements (PSAs) which is a collaborative production by the Vital Strategies Indonesia (VSI) and the Ministry of Health of the Republic of Indonesia. The results of this study revealed that there is still a lack of anti-smoking PSAs in terms of quantity and quality. The study results show that identifying PSAs with high exposures to the messages (and counted by numbers of likes and viewers) is problematic because these numbers do not guarantee viewers accept and respond positively to the messages. However, from the 23 videos uploaded on YouTube, the number of likes and positive responses tended to be more than the number of dislikes and negative tone. It indicates that viewers prefer and respond positively to the PSAs, even though the numbers of likes and positive responses of \#suaratanparokok PSAs is relatively small compared to the numbers of likes and positive responses of other commercial advertisements, especially cigarette advertisements.

This study has limitation because focuses only on the 23 anti-smoking PSAs on YouTube. Further study is necessary to capture and explore viewers' exposure, engagement, and respond to other messages addressing the adverse effects of smoking on YouTube or other social media platforms. However, the content analysis of the \#suaratanparokok videos provide an illustration that the message about the harms of smoking is wellresponded and well-accepted by the audiences' community. These messages have the potential to influence and change a person's behaviour, as stated in positive comments that support the content of the PSAs. 
The involvement of many parties is required to increase public awareness and understanding of the dangers of smoking and its impact on the people around them. Effective and meaningful anti-smoking PSAs on YouTube is an effective strategy in encouraging people to quit smoking. However, the PSAs must also be accompanied by determining the right segmentation, involving well-known influencers or YouTubers who have many followers and who care about the danger of cigarette consumption on young people. This strategy helps the PSAs to have a significant impact on people. For YouTube, the impression of effectiveness is measured by a large number of views/viewers. But relying merely on a YouTube account with a small number of subscribers will be difficult to measure its effectiveness. Besides engaging with influencers or YouTubers, the dissemination of anti-smoking PSAs must include a media integration strategy, that is allowing the PSAs to be visible on other social media platforms such as Twitter, Facebook, and Instagram, and on mainstream media, such as through talk shows, comedies, or movies on television and radio.

\section{REFERENCES}

Astuti, P. A. S., Assunta, M., \& Freeman, B. (2018). Raising generation 'A': a case study of millennial tobacco company marketing in Indonesia. Tobacco Control, 27(1), 4149. http://dx.doi.org/10.1136/tobaccocontrol-2017-054131

Badan Penelitian dan Pengembangan Kesehatan. (2018). Hasil Utama Riskesdas 2018 (2018) [Data set]. Kementrian Kesehatan Republik Indonesia.

Chung J. E. (2015). Antismoking campaign videos on YouTube and audience response: Application of social media assessment metrics. Computers in Human Behaviour, 51(A),114-21. https://doi.org/10.1016/j.chb.2015.04.061

Davis R. M., Gilpin E. A., Loken B., Viswanath K., \& Wakefield, M.A. (Eds.). (2008). The role of the media in promoting and reducing tobacco use. U.S. Department of Health and Human Services National Institutes of Health.

Drope, J., Schluger, N., Cahn, Z., Drope, J., Hamill, S., Islami, F., Liber, A., Nargis, N., \& Stoklosa, M. The Tobacco Atlas (6th ed.) American Cancer Society, Inc.

Durkin, S., Bayly, M., Cotter, T., Mullin, S., \& Wakefield, M. (2013). Potential effectiveness of anti-smoking advertisement types in ten low and middle income countries: Do demographics, smoking characteristics and cultural differences matter? Social Science \& Medicine, 98, 204-213. http://doi.org/10.1016/j.socscimed.2013.09.022

Ennett, S. T. \& Bauman, K. E. (1994). The contribution of influence and selection to adolescent peer group homogeneity: the case of adolescent cigarette smoking. 
Journal of personality and social psychology, 67(4), 653-663. http://doi.org/10.1037/0022-3514.67.4.653

Fauzi, R., Ma'aruf, M. A., Bonita, Puspawati, N., Soewarso, K., Antojo, A., \& Bam, T. S. (2018). Hubungan Terpaan Iklan, Promosi, Sponsor Rokok dengan Status Merokok di Indonesia. Tobacco Control Support Center - Ikatan Ahli Kesehatan Masyarakat Indonesia (TCSC IAKMI) International Union Against Tuberculosis and Lung Disease (The Union).

Freeman, B. (2012). New media and tobacco control. Tobacco control, 21(2), 139-144. http://dx.doi.org/10.1136/tobaccocontrol-2011-050193

GLOBOCAN (2018). Cancer today. International Agency for Research on Cancer. http://gco.iarc.fr/.

Graham, H. \& Der, G. (1999). Patterns and predictors of smoking cessation among British women. Health Promotion International, 14(3), 231-40. http://doi.org/10.1093/heapro/14.3.231

Hong, Y. H., Soh, C. H., Khan, N., Abdullah, M. M. B., \& Teh, B. H. (2013). Effectiveness of anti-smoking advertising: the roles of message and media. International Journal of Business and Management, 8(19), 55-62. http://doi.org/10.5539/ijbm.v8n19p55

Indonesia. Peraturan Pemerintah Republik Indonesia Nomor 109 Tahun 2012 tentang pengamanan bahan yang mengandung zat adiktif berupa produk tembakau bagi kesehatan. Department of Health Republic of Indonesia.

Jackson, C. \& Henriksen, L. (1997). Do as I say: parent smoking, antismoking socialization, and smoking onset among children. Addictive behaviours, 22(1), 107-114. https://doi.org/10.1016/0306-4603(95)00108-5

Jefferis, B., Graham, H., Manor, O., \& Power, C. (2003). Cigarette consumption and socioeconomic circumstances in adolescence as predictors of adult smoking. Addiction, 98(12), 1765-1772. http://doi.org/10.1111/j.1360-0443.2003.00552.x

Kandel, D. B. \& Wu, P. (1995). The contributions of mothers and fathers to the intergenerational transmission of cigarette smoking in adolescence. Journal of research on adolescence, 5(2), 225-252.

Lucas, K. \& Lloyd, B. (1999). Starting smoking: Girls' explanations of the influence of $\begin{array}{lll}\text { peers. Journal of adolescence, 22(5), 647-55. } & \end{array}$ https://doi.org/10.1006/jado.1999.0260 
Luke, C. (2007). As Seen on TV or was That My Phone? New Media Literacy. Policy Futures in Education, 5(1), 50-58. http://doi.org/10.2304/pfie.2007.5.1.50

Luke. D., Esmundo, E., \& Bloom, Y. (2000). Smoke signs: patterns of tobacco billboard advertising in a metropolitan region. Tobacco Control, 9(1), 16-23. http://dx.doi.org/10.1136/tc.9.1.16

Manaf, R. A. \& Shamsuddin, K. (2008). Smoking among young urban Malaysian women and its risk factors. Asia Pacific Journal of Public Health, 20(3), 204-213. https://doi.org/10.1177/1010539508316973

Mutmainnah, N., Hendriyani, \& Utaminingtyas, I. (2020). Outsmarting regulation: how tobacco websites and social media targeting young people. International Journal of Communication and Society, 2(1), 12-19. https://doi.org/10.31763/ijcs.v2i1.108

Prabandari, Y. S. \& Dewi, A. (2016). How do Indonesian youth perceive cigarette advertising? A cross-sectional study among Indonesian high school students. Global health action, 9(1), 30914. https://doi.org/10.3402/gha.v9.30914

Putra, H. S., Rosemary, R., Yanuar, D., \& Ahsan, A. (2020). The Effect of Cigarette Advertising on Smoking Behaviour of Students in Banda Aceh City, Indonesia. Jurnal Komunikasi: Malaysian Journal of Communication, 36(2), 348-363. https://doi.org/10.17576/jkmjc-2020-3602-21

Redaksi Sehat Negeriku. (2019, July 17). HTTS 2019: Jangan Biarkan Rokok Merenggut Napas Kita. Sehat Negeriku. https://sehatnegeriku.kemkes.go.id/baca/rilismedia/20190711/1030815/htts-2019-jangan-biarkan-rokok-merenggut-napaskita/

Rosemary, R. (2011). A content analysis of tobacco advertising and promotion for Indonesian tobacco brands on YouTube. [Unpublished doctoral dissertation]. University of Sydney.

Rosemary, R. (2020). Women's interpretation of anti-smoking messages in Indonesia: An audience analysis (submitted). (Publication No. 22125). [Doctoral dissertation, University of Sydney]. University of Sydney.

Sargent, J. D., Gibson, J., \& Heatherton, T. F. (2009). Comparing the effects of entertainment media and tobacco marketing on youth smoking. Tobacco Control, 18(1), 47-53. https://doi.org/10.1136/tc.2008.026153 
Seatca. (2018). The Tobacco Control Atlas: ASEAN Region (4th ed.). Southeast Asia Tobacco Control Alliance (SEATCA).

Shi, R., Messaris, P., \& Cappella, J. N. (2014). Effects of online comments on smokers' perception of antismoking public service announcements. Journal of ComputerMediated Communication, 19(4), 975-990. https://doi.org/10.1111/jcc4.12057

Siplawfirm. (2018, September 23). Menteri Kesehatan Terbitkan Surat Menteri Tentang Pemblokiran Iklan Rokok Di Internet. Siplawfirm. https://siplawfirm.id/menterikesehatan-terbitkan-surat-menteri-tentang-pemblokiran-iklan-rokok-diinternet/

Soerojo, W. (2014). Survey on pictorial health warning compliance in indonesia (report from 7 districts). University of Indonesia.

Sebayang, S. K., Rosemary, R., Widiatmoko, D., Mohamad, K., \& Trisnantoro, L. (2012). Better to die than to leave a friend behind: industry strategy to reach the young. Tobacco control, 21(3), 370-372. https://doi.org/10.1136/tobaccocontrol2011-050223

Tobacco Control. (2019, September 23). Vital Strategies, Inc. https://www.vitalstrategies. org/.

WHO Indonesia. (2020, May 30). Pernyataan: Hari Tanpa Tembakau Sedunia 2020. WHO Indonesia. $\quad$ https://www.who.int/indonesia/news/detail/30-05-2020pernyataan-hari-tanpa-tembakau-sedunia-2020.

WLF. (2015). Indonesia health communications campaigns: World Lung Foundation; 2015. World Lung Foundation. http://worldlungfoundation.org/ht/d/sp/i/20872/pid/20872. 